\title{
Role of taurine on acid secretion in the rat stomach
}

Kai-Han Huang ${ }^{1,2}$, Chia-Chieh Chang ${ }^{3}$, Jau-Der Ho ${ }^{1,2}$, Ruey-Hwa Lu ${ }^{4^{*}}$, Li Hsueh Tsai ${ }^{3,5^{*}}$

\begin{abstract}
Background: Taurine has chemical structure similar to an inhibitory neurotransmitter, $\gamma$-aminobutyric acid (GABA). Previous studies on GABA in the stomach suggest GABAergic neuron is involved in acid secretion, but the effects of taurine are poor understood.
\end{abstract}

Methods: The effects of taurine on acid secretion, signal transduction, and localization of taurinergic neurons were determined in the rat stomach using everted whole stomach, RIA kit and immunohistochemical methods.

Results: We used antibodies against taurine-synthesizing enzyme, cysteine sulfuric acid decarboxylase (CSAD), and taurine. CSAD- and taurine-positive cells were found in the muscle and mucosal layers. Distributions of CSAD- and taurine-positive cells in both mucosal and muscle layers were heterogeneous in the stomach. Taurine at $10^{-9} \sim 10^{-4}$ $\mathrm{M}$ induced acid secretion, and the maximum secretion was at $10^{-5} \mathrm{M}, 1.6$-fold higher than the spontaneous secretion. Taurine-induced acid secretion was completely inhibited by bicuculline and atropine but not by cimetidine, proglumide, or strychnine. Atropine and tetrodotoxin (TTX) completely inhibited the acid secretion induced by low concentrations of taurine and partially inhibited induced by high concentrations. Verapamil, a calcium blocker agent, inhibited acid output elicited by taurine. We assumed all $\mathrm{Ca}^{2+}$ channels involved in the response to these secretagogues were equally affected by verapamil. Intracellular cAMP (adenosine 3', 5'-

monophosphat) in the stomach significantly increased with taurine treatment in a dose-dependent manner. High correlation ( $r=0.859, p<0.001)$ of taurine concentrations with cAMP was observed.

Conclusions: Our results demonstrated for the first time in taurine-induced acid secretion due to increase intracellular calcium may act through the A type of GABA receptors, which are mainly located on cholinergic neurons though CAMP pathway and partially on nonneuronal cells in the rat stomach.

\section{Background}

Inhibitory amino acids (IAAs), e.g., taurine and $\gamma$-aminobutyric acid (GABA), are present in various parts of the vertebrate central nervous system (CNS) and serve as major inhibitory neurotransmitters [1]. Taurine is the most abundant free amino acid in the body and is present at high concentrations during development. It is synthesized from cysteine via oxidation of cysteine to cysteinesulfinate by the enzyme cysteine dioxygenase (CDO), followed by the decarboxylation of cysteinesulfinate to hypotaurine, catalyzed by cysteine sulfuric acid decarboxylase (CSAD) [2,3].

\footnotetext{
* Correspondence: DAK23@tpech.gov.tw; Ihtsai@tmu.edu.tw

${ }^{3}$ Graduate Institute of Medical Sciences, College of Medicine, Taipei Medical University, Taipei 11031, Taiwan

${ }^{4}$ Department of General Surgery, Taipei City Hospital, Taipei 10341, Taiwan Full list of author information is available at the end of the article
}

Taurine has many physiological properties, including membrane stabilization, osmoregulation, neuromodulation, regulation of calcium homeostasis, antioxidation, modulation of ion flux, and serving as a neurotransmitter or neuromodulator [4-8].

Taurine has chemical structure similar to an inhibitory neurotransmitter GABA which binds to $\mathrm{GABA}_{\mathrm{A}}$, $\mathrm{GABA}_{B}$, and the glycine receptor [9-12]. It protected the gastric mucosa against certain lesions [13-16]. Taurine is stored in parietal cells [17] and smooth muscle [18]. It plays an import role in stabilizing membranes [5], and modulating acid secretion and gastric motility.

Studies on GABA in the enteric nervous system suggested that GABAergic neurons are not confined to the CNS, but rather these neurons also exist in the peripheral autonomic nervous system [19-21] and are involved in acid secretion [22] and motility [23]. However, the

\section{Biomed Central}


functions of taurine in gastric secretion are largely unknown. Recently, pharmacological studies have found that taurine binds to GABA receptors [24-26]. The purpose of the study was to determine if taurine also regulates gastric acid secretion via GABA receptors in the stomach.

Localization of taurine in the CNS used enzymatic synthesis of CSAD enzymes [10,11]. CSAD forms antibodies in the hippocampus, cerebellum, and retina [27-29]. However, no detailed information is available for the stomach.

In this communication, we demonstrated that taurine might regulate acid secretion through A- type GABA receptors and elevation of cAMP in the stomach. The distribution of taurine-containing cells in the rat stomach was localized immunohistochemically using specific antibodies against taurine and CSAD.

\section{Methods}

\section{Chemical and antibodies}

Taurine, bicuculline, cimetidine, proglumide, atropine, strychnine, tetrodotoxin (TTX), verapamil, and 3-isobutyl1-methylxanthane (IBMX) were purchased from Sigma Chemical (St. Louis, MO, USA). The $\left[{ }^{3} \mathrm{H}\right]$ cAMP (adenosine 3', 5'-monophosphat) assay system was obtained from Amersham (Buckinghamshire, UK). Anti-taurine was purchased from Abcam (Cambridge, UK). AntiCSAD was a gift from Dr. Wu, J-Y (Department of Biomedical Science, Florida Atlantic University, Boca Raton, Florida 33431, USA). Other chemicals used were of reagent grade and were obtained from various commercial sources.

\section{Animals}

Male Sprague-Dawley rats (National Laboratory Animal Center, Taipei, Taiwan) weighing 180 250 g were used. They were housed in group cages under controlled illumination (light cycle, 08:00 20:00), relative humidity of $30 \% \sim 70 \%$, and temperature $\left(23 \pm 1^{\circ} \mathrm{C}\right)$ with free access to a laboratory diet (LabDiet, Brentwood, MO, USA) and tap water. Approval for the study was obtained from the Animal Care and Use Committee of Taipei Medical University.

\section{Immunohistochemical Procedures}

The immunohistochemical procedures were described in detail elsewhere [30]. Briefly, male Sprague-Dawley rats were initially anesthetized with an intraperitoneal injection of sodium pentobarbital $(50 \mathrm{mg} / \mathrm{kg})$, followed by perfusion with $1 \mathrm{~L}$ saline at $37^{\circ} \mathrm{C}$, and subsequent fixation with $4 \%$ paraformaldehyde in phosphate-buffered saline (PBS: $50 \mathrm{mM}$ potassium phosphate buffer $(\mathrm{pH}$ 7.4) containing $0.9 \% \mathrm{NaCl}$ ) at $4^{\circ} \mathrm{C}$. After fixation, the tissue was frozen, embedded in OTC compound, mounted on a gelatinized slide, and sectioned at $20 \sim 30 \mu \mathrm{m}$. The body and antrum of the stomach were used for immunohistochemical studies by the peroxidase-antiperoxidase (PAP) technique [31]. Tissue sections were treated in the following manner: (i) incubated with anti-CSAD $(1: 300)$ or anti-taurine $(1: 1000$; Abcam) (diluted in $0.1 \mathrm{M}$ PBS containing $0.1 \%$ Triton $\mathrm{X}-100)$ for $16 \mathrm{~h}$ at $4^{\circ} \mathrm{C}$; (ii) rinsed twice with $0.1 \mathrm{M} \mathrm{PBS}$; (iii) incubated in PAP solution (at a 1:50 dilution) in $50 \mathrm{mM}$ Tris- $\mathrm{HCl}$ ( $\mathrm{pH}$ 7.6) for $2 \mathrm{~h}$ at room temperature; (iv) rinsed with $50 \mathrm{mM}$ Tris- $\mathrm{HCl}$ (pH 7.6) twice; (v) incubated in a solution containing $0.05 \%$ diaminobenzidine and $0.01 \%$ $\mathrm{H}_{2} \mathrm{O}_{2}$ in $50 \mathrm{mM}$ Tris- $\mathrm{Cl}$ ( $\mathrm{pH}$ 7.6), for $8 \sim 10 \mathrm{~min}$ at room temperature; and (vi) the sections were dehydrated, mounted on slides with Permount (Fisher), and covered with cover slips for light-microscopic examination. For control experiments, sections were treated exactly as those described above for the experimental group except that antibodies had been preabsorbed with an excess of respective antigens and then were used to replace the anti-taurine or anti-CSAD. Anti-CSAD as described elsewhere [27]. Taurine-containing cells were determined by using specific antibodies from Abcam. For the control experiments anti-taurine and anti-CSAD sera were replaced with preimmune rabbit serum at the same dilution.

\section{Experiments on Everted Whole Stomachs}

Experiments on everted whole stomachs were performed as described elsewhere [30], with slight modifications. Briefly, male Sprague-Dawley rats (weighing 180 250 g) were deprived of food overnight, and allowed free access to water to ensure that the stomach was free of solid contents. A rat was decapitated, and its stomach was immediately removed. The entire everted organ was then placed in a 20-ml organ bath containing a mucosal saline solution (in $\mathrm{mM}: \mathrm{NaCl}, 119 ; \mathrm{KCl}, 4.7 ; \mathrm{CaCl}_{2}, 2.5$; and glucose, 5.6; pH 5.2) at $30 \pm 1^{\circ} \mathrm{C}$ and continuously bubbled with $100 \% \mathrm{O}_{2}$. The serosal side was perfused with a serosal saline solution (in $\mathrm{mM}: \mathrm{NaCl}, 119 ; \mathrm{KCl}$, 4.7; $\mathrm{CaCl}_{2}, 2.5 ; \mathrm{NaHCO}_{3}, 25 ; \mathrm{KH}_{2} \mathrm{PO}_{4}, 1.03$; and glucose, 5.6; $\mathrm{pH} 7.4$ ) at a rate of $1 \mathrm{ml} / \mathrm{min}$ under the same conditions as described above except that $100 \% \mathrm{O}_{2}$ was replaced by a mixture of $95 \% \mathrm{O}_{2}$ and $5 \% \mathrm{CO}_{2}$. One hour after equilibration of the organ, the mucosal saline solution was replaced every 15 min during the experiment. Only the serosal side of the preparation was exposed to the test drugs.

Spontaneous acid secretion was determined for 60 min before adding the test drugs. Acid secretion was allowed to last for an additional hour. The acid accumulated on the mucosal side was initially titrated to $\mathrm{pH} 5.2$ and pH 7.0 with $0.1 \mathrm{mM} \mathrm{NaOH}$. Responses of the stomach to drug treatments were expressed as the 
secretory ratio $(\mathrm{R})$, which was defined as:

$\mathrm{R}=$ (secretion evoked by the drug)/(average spontaneous secretion).

The average spontaneous secretion was calculated using acid from the four periods immediately before exposure to the test drugs. Finally, the secretory ratio at the peak response was measured to assess the concentration-response curves.

\section{Measurement of the cAMP Concentration}

Stomachs were cut into $0.4 \times 0.4-\mathrm{mm}$ cubes with a Mellwain tissue chopper. After preincubation in a serosal saline solution containing $0.5 \mathrm{mM}$ IBMX maintained at $37^{\circ} \mathrm{C}$ and continuously bubbled with $95 \% \mathrm{O}_{2}$ and $5 \%$ $\mathrm{CO}_{2}$. They were incubated in medium containing $0.5 \mathrm{mM}$ IBMX for $30 \mathrm{~min}$. The mixture was incubated $2 \mathrm{~min}$ in the presence or absence of different doses of taurine $\left(10^{-9} \sim 10^{-4} \mathrm{M}\right)$ according to protocols provided by the supplier (RPA 538; Amersham Biosciences).

After incubation, tissues were homogenized in 6\% trichloroacetic acid, followed by centrifugation at 3,000 $\mathrm{g}$ and $4^{\circ} \mathrm{C}$ for $15 \mathrm{~min}$. The supernatant was neutralized to $\mathrm{pH} 7.4$ with $1 \mathrm{M}$ Tris, followed by extraction with ether four times. The ether extracts were combined and dried. The cAMP concentration was determined using a commercial RIA kit. The homogenized solution was solubilized in $3 \mathrm{~N} \mathrm{NaOH}$ and used for protein determination as previously described [32].

\section{Statistical Analysis}

Results are expressed as the mean \pm SEM $(n=$ sample number). Data were analyzed by Dunnett's test or Student's $t$-test; a $p$ value of $\leq 0.05$ was considered statistically significant.

\section{Results}

\section{Immunohistochemical Studies}

Numerous myenteric ganglia scattered in the smooth muscle layers of the rat stomach were CSAD positive. CSAD-fibers were to run in muscle layers and in the deep in the muscle layer. CSAD-positive fibers were concentrated in the myenteric plexus and submucosal plexus (Figure $1 \mathrm{~A}$ and $1 \mathrm{D}$ ). In the mucosal layers numerous CSAD-immunoreactive cells could easily identified in the deep mucosal layers (Figure $1 \mathrm{~B}$ and $1 C)$. In addition, numerous taurine-positive myenteric ganglia and fibers distributed all over the muscle layers of the rat stomach (Figure 2). CSAD- and taurineimmunoreactive cells were observed along the length of the mucosal gland (Figure $1 \mathrm{C}$ and Figure 2C). No immunoreactive cells were found when non-immune serum was replaced CSAD or taurine antibody.

\section{Acid Secretion}

Spontaneous acid secretion reached a steady state after equilibration for $2 \mathrm{~h}$. The average spontaneous acid secretion after equilibration was $1.232 \pm 0.067 \mu$ mole $/ 15 \mathrm{~min}$, which was taken as the control value. Taurine did not affect the spontaneous acid secretion at $10^{-6} \mathrm{M}$ (Figure 3 ).
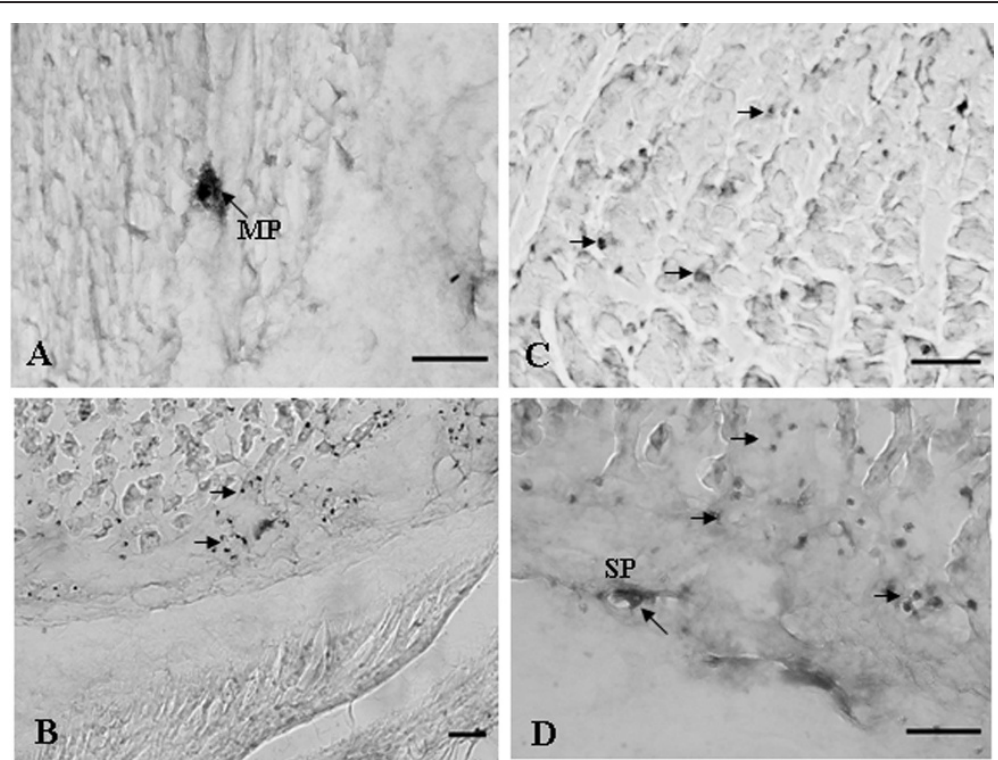

Figure 1 Immunohistochemical localization of cysteine sulfuric acid decarboxylase (CSAD) in the rat stomach. (A) Light micrography of a transverse section of the muscle layer showing CSAD-immunoreactive processes in the Body. (B) Light micrograph of cross section showing CSADpositive processes in the antrum. (C) CSAD-immunoreactive cells occurred mostly in glands of the gastric mucosa. (D) CSAD-positive cell processes in the deep of mucosal layers. MP, myenteric plexus; SP, submucosa plexus. Arrowheads indicate CSAD-positive processes. Bar $=50 \mu \mathrm{m}$. 
The taurine $\left(10^{-6} \mathrm{M}\right)$-induced acid secretion was completely inhibited by TTX at $3 \times 10^{-7} \mathrm{M}$ and atropine at $10^{-6} \mathrm{M}$ (Figure 3A and 3B). A histamine $\mathrm{H}_{2}$-receptor antagonist, cimetidine, at $10^{-6} \mathrm{M}$ and an antagonist for the gastrin receptor, proglumide, at $3 \times 10^{-4} \mathrm{M}$, did not significantly affect taurine at $10^{-6} \mathrm{M}$-induced acid secretion (Figure 3C and 3D).

Taurine at $10^{-9} \sim 10^{-4} \mathrm{M}$ increased the acid secretion in a concentration-dependent fashion, and the $\mathrm{ED}_{50}$ value for taurine was $1.2 \times 10^{-7} \mathrm{M}$. The maximum acid secretion occurred as taurine at $10^{-5} \mathrm{M}$ with a secretory ratio of $1.6(n=6)$ (Figure $4 \mathrm{~A})$. Taurine increased acid secretion in the stomach in a dose-dependent manner. Taurine concentration highly correlated $(r=0.795, p<$ 0.001) with acid secretion (Figure 4B).

TTX at $3 \times 10^{-7} \mathrm{M}$ abolished the acid secretion induced by taurine at $\leq 10^{-6} \mathrm{M}$, but did not completely inhibit induction by taurine at $>10^{-6} \mathrm{M}$ (Figure 5A).
Atropine, a muscarinic receptor antagonist, completely inhibited the acid secretion induced by taurine at $\leq 10^{-7}$ $M$, but only a certain extent of the secretion induced by taurine concentrations $>10^{-7} \mathrm{M}$ (Figure 5B). The TTXinsensitive component was $<15 \%$ of the response obtained by taurine at $\geq 10^{-6} \mathrm{M}$ and was similar to the atropine-insensitive component.

Bicuculline $\left(10^{-6} \mathrm{M}\right)$, an antagonist of the $\mathrm{GABA}_{\mathrm{A}}$ receptor, produced a concentration-dependent decrease in taurine-induced acid secretion at $10^{-9} \sim 10^{-4} \mathrm{M}$. Bicuculline at $10^{-6} \mathrm{M}$ abolished the acid secretion induced by taurine at $\leq 10^{-6} \mathrm{M}$, but did not completely inhibit induction by taurine at $>10^{-6} \mathrm{M}$ (Figure 6). Acid secretion was not affected by baclofen, an agonist of the $\mathrm{GABA}_{\mathrm{B}}$ receptor (data not shown).

Strychnine, a glycine receptor antagonist, did not significantly affect taurine-stimulated acid secretion at $10^{-6} \mathrm{M}$ (Figure 7).

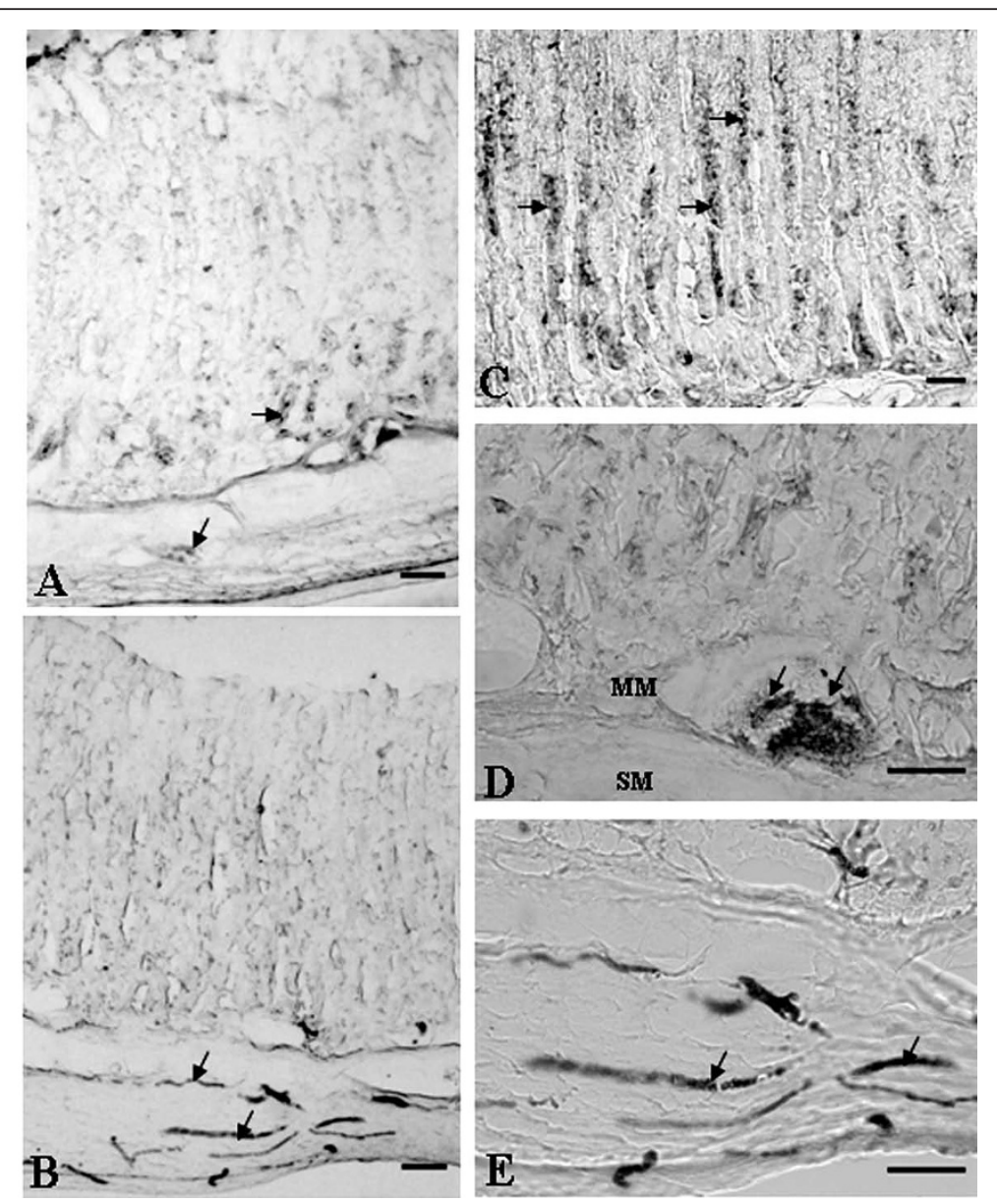

Figure 2 Immunohistochemical localization of taurine in the rat stomach. (A) Light micrography of cross-section showing taurine-positive processes in the antrum. (B) Light micrography of a cross-section showing taurine-immunoreactive processes in the body. (C), (D) A higher magnification of the area in (A) showing taurine-positive processes in the antrum. (E) A higher magnification of the area in (B) showing taurinepositive processes in the body. Taurine-immunoreactive cells mostly occurred in glands of the muscle layers. MM, muscularis mucosa; SM, submucosa. Arrowheads indicate taurine-positive processes. Bar $=50 \mu \mathrm{m}$. 

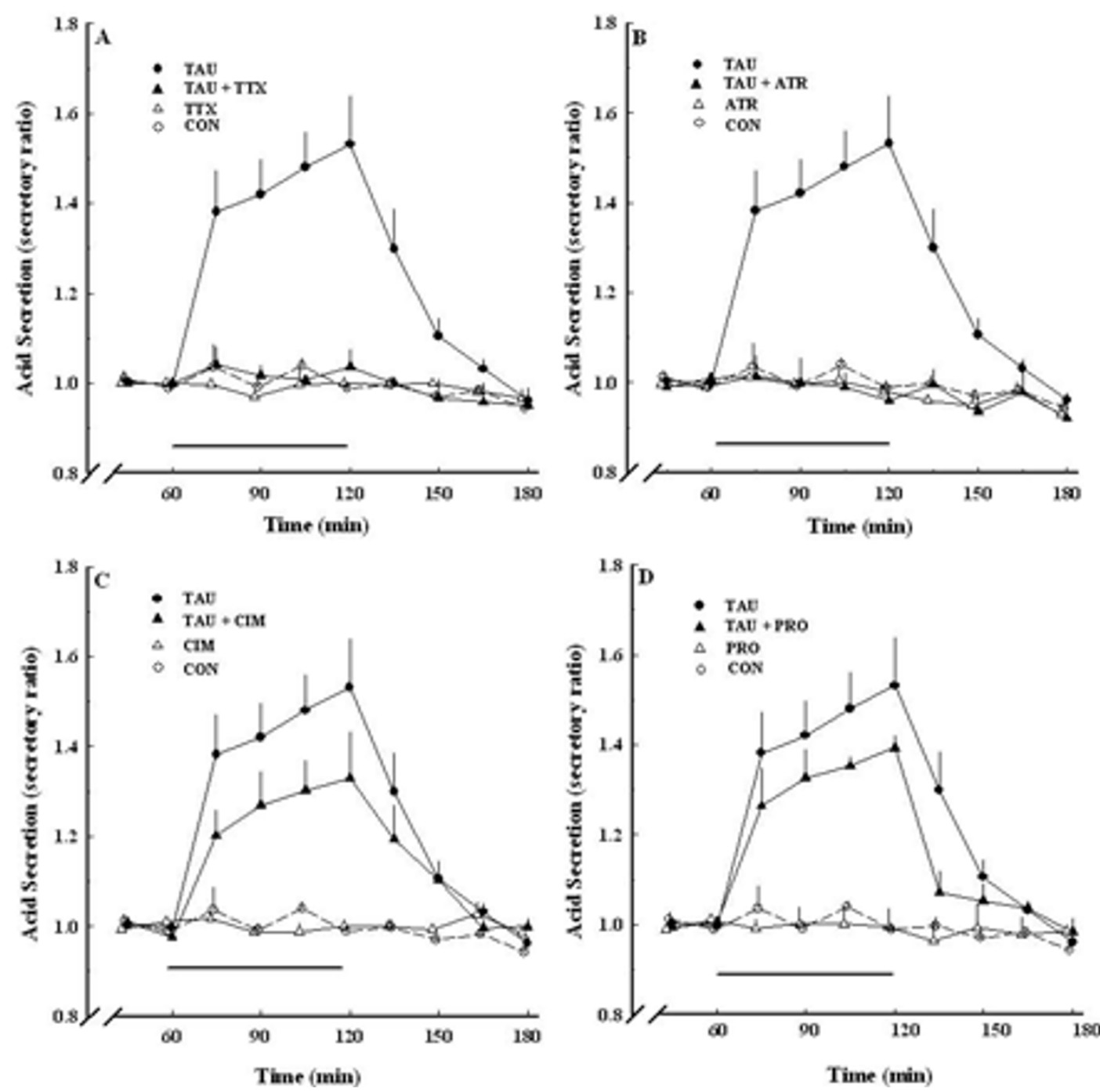

Figure 3 Taurine-induced acid secretion in the absence and presence of TTX (A), atropine (B), cimetidine (C), and proglumide (D). TAU, $10^{-6} \mathrm{M}$ taurine alone $(\bullet, n=6)$; $\mathrm{CON}$, control $(0, n=6) ; \pi \mathrm{X}, 3 \times 10^{-7} \mathrm{M}$ TTX alone $(\Delta, n=6)$; TAU+TTX, $10^{-6} \mathrm{M}$ taurine and $3 \times 10^{-7} \mathrm{M} T \mathrm{TX}(\boldsymbol{\Delta}, n$ $=6) ; \operatorname{ATR}, 10^{-6} \mathrm{M}$ atropine alone $(\Delta, n=6) ; \operatorname{TAU}+\mathrm{ATR}, 10^{-6} \mathrm{M}$ taurine and $10^{-6} \mathrm{M}$ atropine $(\boldsymbol{\Delta}, n=6) ; \mathrm{CIM}, 10^{-6} \mathrm{M}$ cimetidine alone $(\Delta, n=6) ; \operatorname{TAU}$ $+\mathrm{CIM}, 10^{-6} \mathrm{M}$ taurine and $10^{-6} \mathrm{M}$ cimetidine $(\mathbf{\Delta}, n=6) ; \mathrm{PRO}, 3 \times 10^{-4} \mathrm{M}$ proglumide alone $(\Delta, n=6) ; \mathrm{TAU}+\mathrm{PRO}, 10^{-6} \mathrm{M}$ taurine and $3 \times 10^{-4} \mathrm{M}$ proglumide $(\boldsymbol{\Delta}, n=6)$. Each point represents the mean \pm SEM.

Verapamil, a calcium blocker agent, had no effect on spontaneous acid secretion, but after $3 \mathrm{~h}$, the secretion rate began to decrease (data not shown). Verapamil $(3 \times$ $\left.10^{-6} \sim 10^{-4} \mathrm{M}\right)$ significantly decreased taurine $\left(10^{-6} \mathrm{M}\right)$ induced acid secretion (Figure 8).

\section{Measurement of the CAMP Concentration}

The gastric mucosa was cut into slices and bubbled in a solution with a mixture of $95 \% \mathrm{O}_{2}$ and $5 \% \mathrm{CO}_{2}$ at $37^{\circ} \mathrm{C}$ in water bath incubation for $2 \mathrm{~min}$. The spontaneous cAMP concentration was $1.673 \pm 0.223$ pmole/mg protein. Taurine at $10^{-9} \sim 10^{-4} \mathrm{M}$ stimulated increases in the intracellular cAMP concentration in the stomach slice in a dose-dependent manner. Therefore, taurine $\left(10^{-6}\right.$ M) markedly increased the cAMP concentration to $100-156 \%$ in the stomach slice (Figure 9).

\section{Discussion}

In this communication we further support the notion that taurine may play an important role in the stomach. First, taurine markedly increases gastric acid secretion. Second, taurine stimulates acid secretion that abolished by TTX, atropine, and bicuculline but not by cimetidine, proglumide, or strychnine. Third, taurine potently 

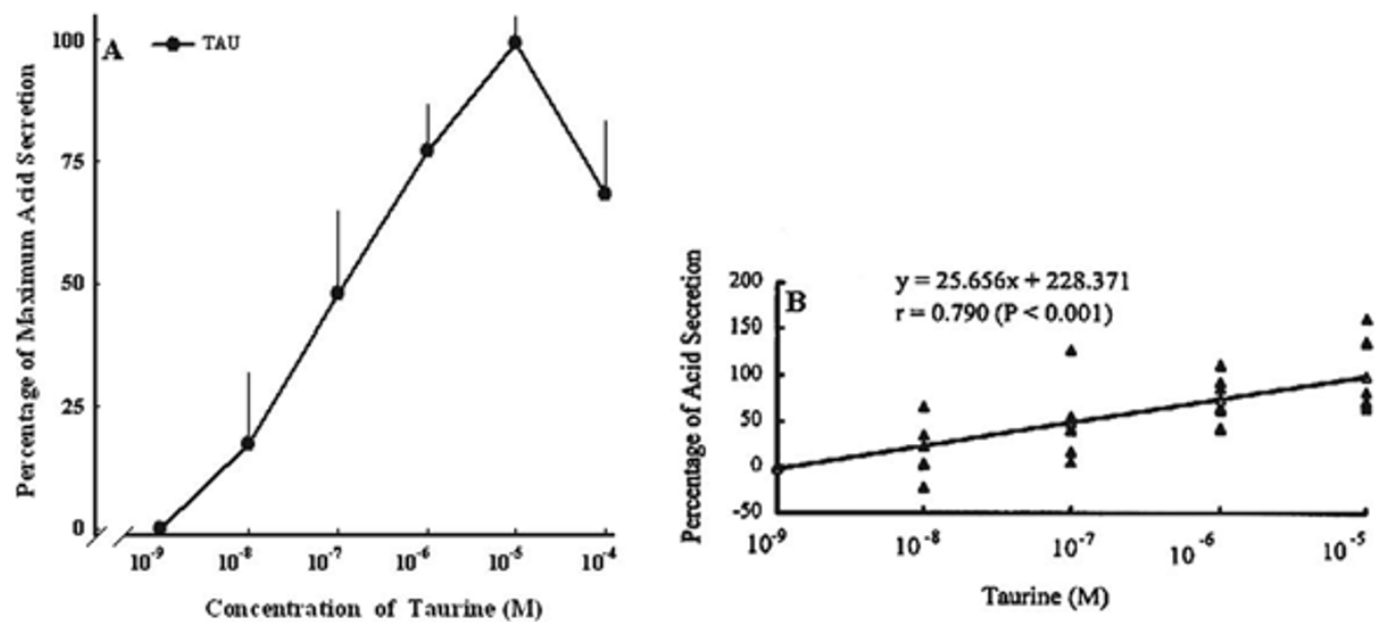

Figure 4 Effect of various doses of taurine-induced acid secretion in the isolated stomach. (A) Dose-dependent curve of taurine-induced acid secretion. (B) Correlation between various doses of taurine and acid secretion. Values are the mean $\pm \operatorname{SEM}(n=6)$.

increases the level of cAMP. Fourth, the presence of taurine-containing cells in the rat stomach is confirmed, as indicated by CSAD- and taurine-positive cells.

We found the presence of taurine-containing cells and taurine-induced acid secretion in the stomach. In the body of the stomach, taurine-immunoreactive cells were observed along the length of the mucosal gland. It had been reported that taurine protects the gastric mucosa from damage caused by monochloramine [33]. Therefore, taurine stored in the mucosal glands may protect cells from self-destruction during oxidation. Taurine-containing cells are present in the myenteric plexus and submucosal plexus of the enteric nervous system in the stomach. Taurinergic neurons in the muscle layer of the gastrointestinal (GI) tract might be involved in motility of the GI tract and the function of endocrine cells as well.

Taurine at $10^{-6} \mathrm{M}$ markedly stimulated acid secretion in the stomach. Spontaneous acid secretion from the preparation was $1.232 \pm 0.067 \mu$ mole $/ 15 \mathrm{~min}$, a value similar to the basal acid secretion in vivo [34] and in vitro [22]. In such preparations, taurine induced acid secretion in a concentration-dependent manner. Therefore, taurine acts not only on the CNS [10,35-37] but also on the stomach itself to induce acid secretion.

The parietal cells apparently possesses specific receptors for histamine, gastrin, and acetylcholine (ACh) [38].
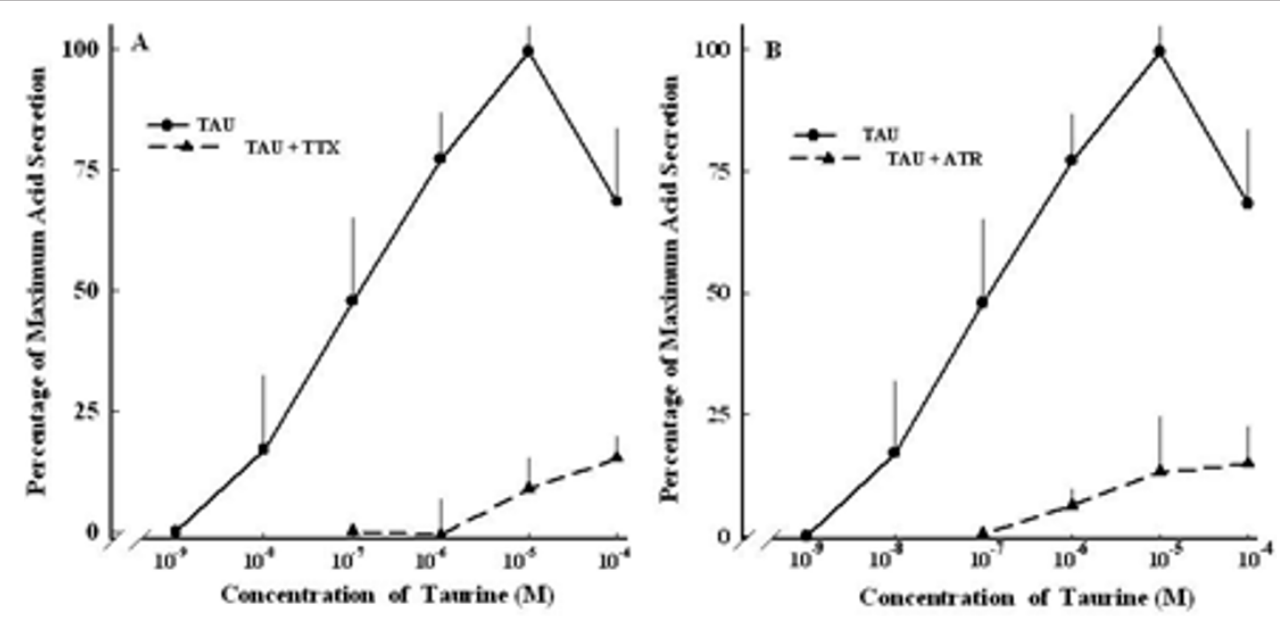

Figure 5 Dose-dependent curve of taurine-induced acid secretion with and without atropine (A) and TTX (B). TAU, taurine alone $(\bullet, n=$ 6); TAU+ATR, taurine and $10^{-6} \mathrm{M}$ atropine; $(\mathbf{\Delta}, n=6)$. TAU+TTX, taurine and $3 \times 10^{-7} \mathrm{M} \mathrm{TTX;}(\mathbf{\Delta}, n=6)$. Each point represents the mean $\pm \mathrm{SEM}$. 

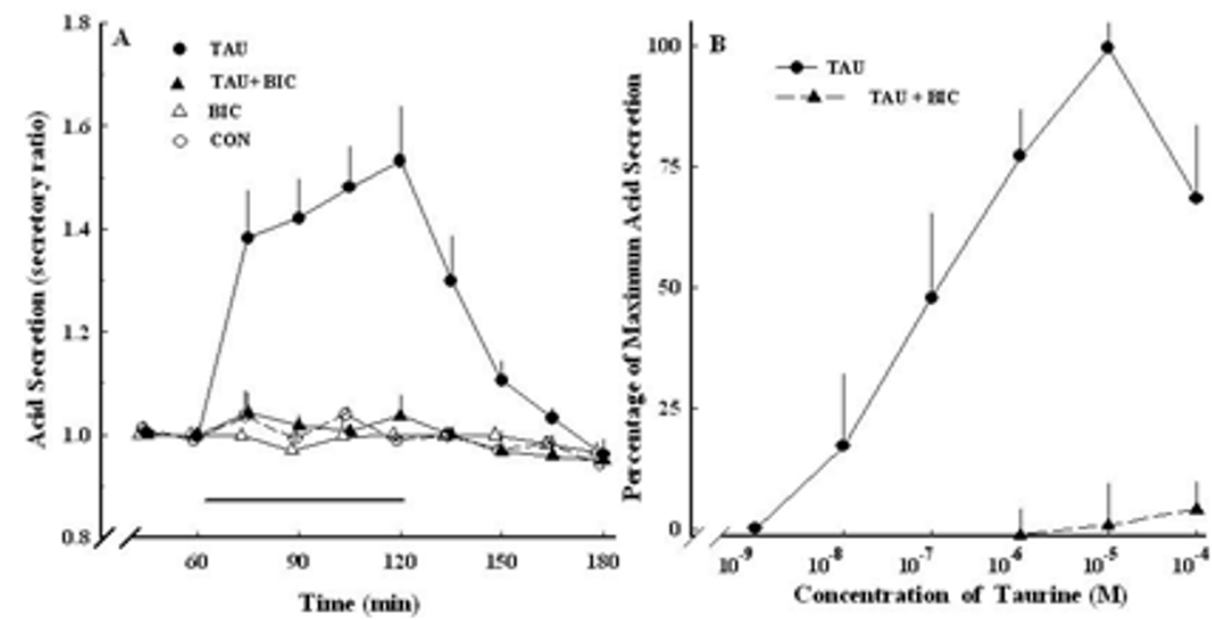

Figure 6 Effect of taurine-induced acid secretion in the absence and presence of bicuculline. (A) Acid secretion expressed as the secretory ratio was plotted against the time duration expressed in minutes. (B) Effect of $10^{-6} \mathrm{M}$ bicuculline on various concentrations of taurine-induced acid secretion. TAU, taurine alone $(\bullet, n=6)$; $\operatorname{CON}$, control $(0, n=6)$; TAU+BIC, taurine and $10^{-6} \mathrm{M}$ bicuculline $(\boldsymbol{\Delta}, n=6)$; BIC, $10^{-6} \mathrm{M}$ bicuculline alone $(\Delta, n=6)$. Data are the mean $\pm \operatorname{SEM}$.

We found that cimetidine and proglumide had no significant effect on the taurine-induced acid secretion. This suggests that histamine and gastrin may not participate in these events.

TTX completely inhibited the acid secretion induced by low taurine concentration $\leq 10^{-7} \mathrm{M}$ but did not

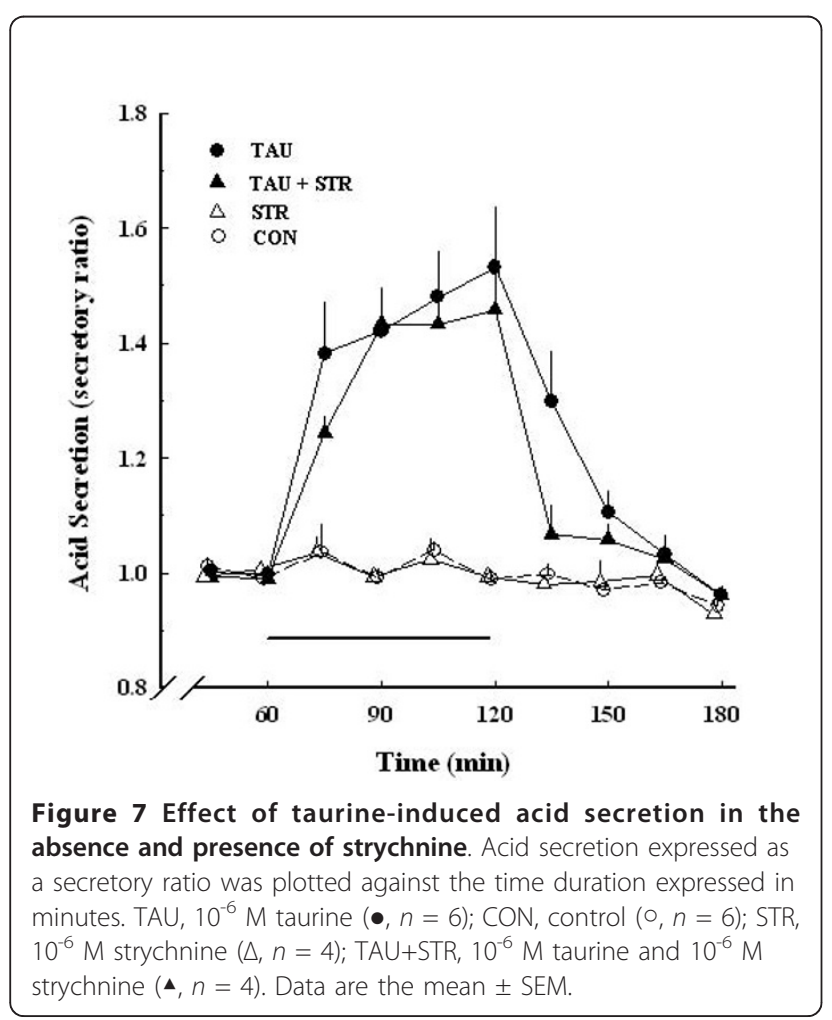

completely inhibit the acid secretion induced by high taurine concentration $>10^{-7} \mathrm{M}$. It's been long recognized that low TTX concentrations blocks nerve conduction due to inhibition of the $\mathrm{Na}^{+}$channel [39]. The inhibitory effect can be attributed blocking nerve conduction. Atropine completely inhibited acid secretion induced by

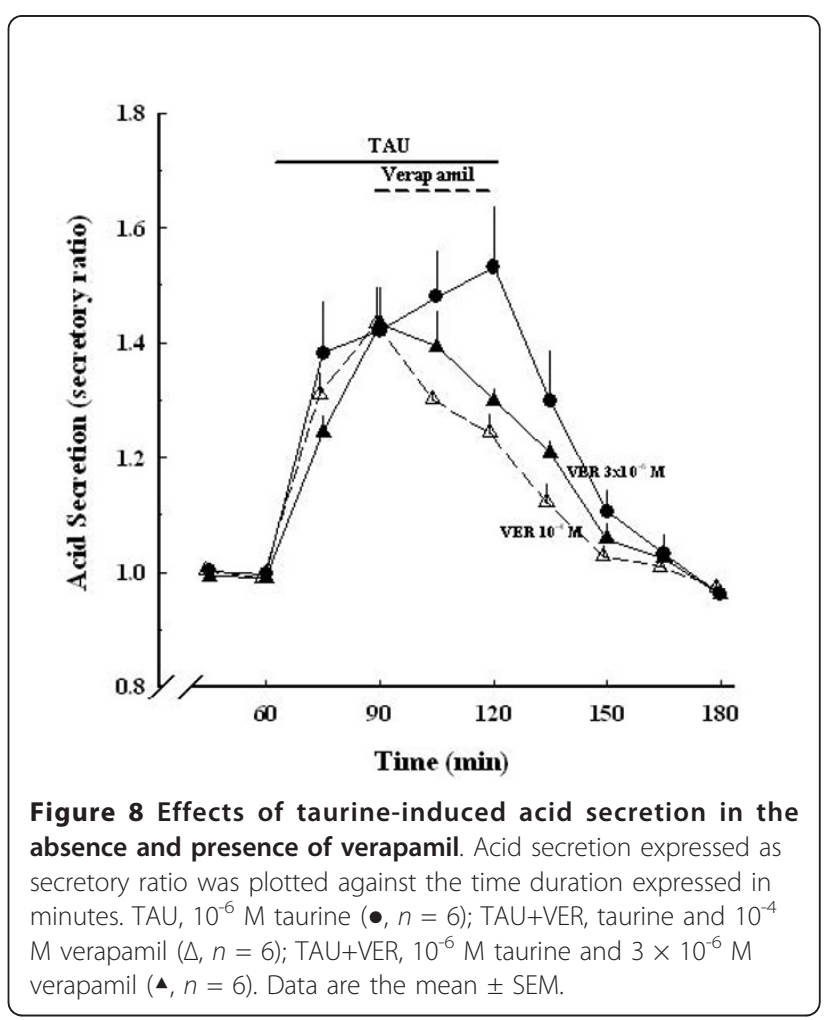




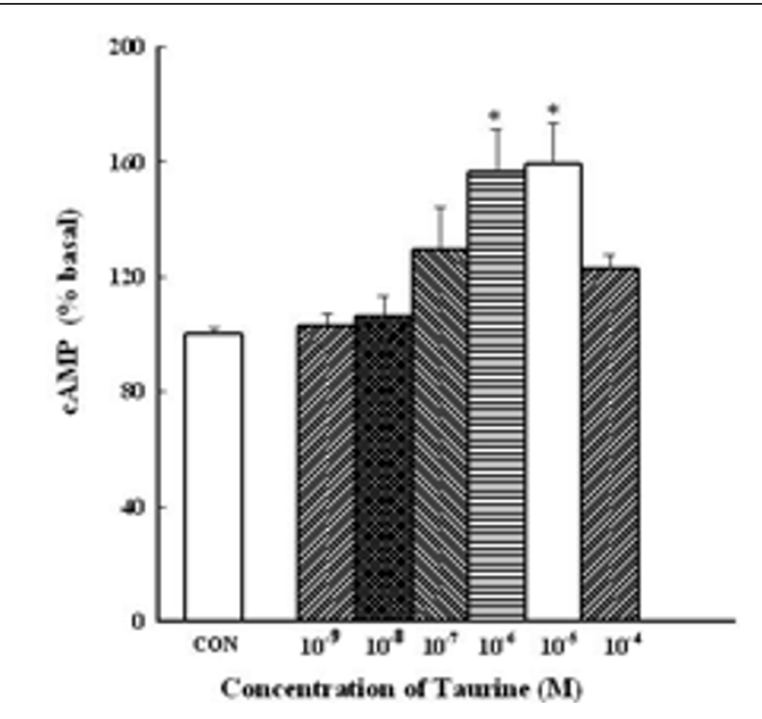

Figure 9 Effects of various concentrations of taurine on cyclic nucleotide levels in mucosal slices of the rat stomach. Samples were incubated at $37^{\circ} \mathrm{C}$ for 30 min before the addition of taurine were treated within $2 \mathrm{~min}$ for the production of CAMP. Each column represents the mean \pm SEM of the percent basal level. ${ }^{*} p<0.05$, significantly differs from the control (C) group $(n=5)$.

low taurine concentrations $\leq 10^{-7} \mathrm{M}$. Therefore, the neuronal pathway involved in acid secretion induced by low taurine concentrations may predominantly involve in cholinergic neurons. Both TTX and atropine completely inhibited the acid secretion induced by low concentrations of taurine $\left(10^{-7} \mathrm{M}\right.$ and under). In contrast, there two components in the acid secretion induced by high concentrations of taurine $\left(10^{-6} \mathrm{M}\right.$ or above). The component insensitive to atropine was to much the same degree as that insensitive to TTX. Whether taurine at high concentrations induces acid secretion by direct action on parietal cells or by indirect actions on other cells remains to be determined.

Taurine is a general agonist for all types of receptors, e.g., $\mathrm{GABA}_{\mathrm{A}}$ receptors and glycine receptors $[10,40]$. Taurine has multiple functions in the brain by participating in both modulation and neurotransmission. Taurineinduced acid secretion was inhibited by bicuculline, an antagonist of the $\mathrm{GABA}_{\mathrm{A}}$ receptor. Strychnine $\left(10^{-6} \mathrm{M}\right)$, a glycine receptor, did not inhibit taurine-induced acid secretion in the stomach. Recently, pharmacological studies have found that taurine binds to GABA receptors [24-26]. There is compelling evidence that taurine interacts with the GABAergic system via the $\mathrm{GABA}_{\mathrm{A}}$ receptor $[24,41-43]$. Taurine as also been shown to activate a taurine receptor [44] or through the glycine receptor [45], but the molecular identity of this receptor has not been fully characterized. Yet, studies also indicate that taurine- produced effects can not be simple function. It is interesting that taurine has also been shown can bind to GABA receptors in the rabbit [46] and the mouse brain [47] but not pig brain [44]. Thus, different animal species and studies models may produce different results. In the present investigation, taurine can increase acid secretion via the $A$ type of $G_{A B A}$ but not $G_{A B A}$ and glycine receptors in the rat stomach.

Gastric acid secretion is not only stimulated via the classical known neuronal and hormonal pathways but also by the $\mathrm{Ca}^{2+}$-Sensing Receptor (CaSR) located at the basolateral membrane of the acid-secretory gastric parietal cell. More recent studies have shown that in addition to these well described receptors a CaSR has been identified and is active in acid-secretory parietal cells [48-50]. Previous investigation found that verapamil, an inhibitor of L-type $\mathrm{Ca}^{2+}$-channels reduced stimulation suggesting that both the release of intracellular $\mathrm{Ca}^{2+}$ from the ER as well as $\mathrm{Ca}^{2+}$ influx into the cell are involved in CaSR-mediated $\mathrm{H}^{+} / \mathrm{K}^{+}$-ATPase activation [48]. Thus, verapamil to block $\mathrm{Ca}^{2+}$-influx from the extracellular space could cause the inhibition of taurineinduced acid secretion.

In addition, taurine effectively increases cAMP concentration in stomach by binding to $\mathrm{GABA}_{\mathrm{A}}$ receptors on cholinergic neurons, resulting in the excitation of cholinergic neurons, followed by the release of ACh. The ACh-binding $\mathrm{M}_{3}$ receptors exist on the membranes of parietal cells. Extracellular $\mathrm{Ca}^{2+}$ appears to be an important factor in the control of gastric secretion [51].

\section{Conclusions}

Our results demonstrated for the first time in taurineinduced acid secretion due to increase intracellular calcium may act through the A type of GABA receptors, which are mainly located on cholinergic neurons though cAMP pathway and partially on nonneuronal cells in the stomach. In light of the findings of previous investigations together with our observations of CSAD- and taurine-positive cells in the stomach and taurine released from CSAD- and taurine-containing neurons, which is also consistent with the above hypothesis.

If peripheral taurine is involved in modulating gastric function is on way of investigation.

\section{Acknowledgements}

The authors would like to thank Prof. Jang-Yen Wu for kind provision with the Anti-CSAD. This study was financially supported by the Taipei City Hospital (95003-62-153).

\section{Author details}

${ }^{1}$ Department of Ophthalmology, Taipei Medical University Hospital, Taipei 11031, Taiwan. ${ }^{2}$ Graduate Institute of Clinical Medicine, College of Medicine, Taipei Medical University, Taipei 11031, Taiwan. ${ }^{3}$ Graduate Institute of Medical Sciences, College of Medicine, Taipei Medical University, Taipei 
11031, Taiwan. ${ }^{4}$ Department of General Surgery, Taipei City Hospital, Taipei 10341, Taiwan. ${ }^{5}$ Department of Physiology, School of Medicine, College of Medicine, Taipei Medical University, Taipei 11031, Taiwan.

\section{Authors' contributions}

This study was designed and supervised by RHL and LHT. Experiments were performed by $\mathrm{KHH}$ and $\mathrm{CCC}$. Analysis of the data was performed by $\mathrm{KHH}$, CCC and JDH. LHT drafted the manuscript and all authors read and approved the final version.

\section{Competing interests}

The authors declare that they have no competing interests.

Received: 22 October 2010 Accepted: 5 February 2011

Published: 5 February 2011

\section{References}

1. Demediuk P, Daly MP, Faden Al: Effect of impact trauma on neurotransmitter and nonneurotransmitter amino acids in rat spinal cord. J Neurochem 1989, 52:1529-1536.

2. Jacobsen JG, Smith LH: Biochemistry and physiology of taurine and taurine derivatives. Physiol Rev 1968, 48:424-511.

3. Ueki I, Stipanuk MH: Enzymes of the taurine biosynthetic pathway are expressed in rat mammary gland. J Nutr 2007, 137:1887-1894.

4. Bouckenooghe T, Remacle C, Reusens B: Is taurine a functional nutrient? Curr Opin Clin Nutr Metab Care 2006, 9:728-733.

5. Huxtable RJ: Physiological actions of taurine. Physiol Rev 1992, 72:101-163.

6. Wright CE, Tallan HH, Lin YY, Gaull GE: Taurine: biological update. Annu Rev Biochem 1986, 55:427-453.

7. Redmond HP, Stapleton PP, Neary P, Bouchier-Hayes D: Immunonutrition: the role of taurine. Nutrition 1998, 14:599-604.

8. Pan C, Giraldo GS, Prentice H, Wu JY: Taurine protection of PC12 cells against endoplasmic reticulum stress induced by oxidative stress. J Biomed Sci 2010, 17(Suppl 1):S17.

9. Albrecht J, Wegrzynowicz M: Endogenous neuro-protectants in ammonia toxicity in the central nervous system: facts and hypotheses. Metab Brain Dis 2005, 20:253-263.

10. Albrecht J, Schousboe A: Taurine interaction with neurotransmitter receptors in the CNS: an update. Neurochem Res 2005, 30:1615-1621

11. Wu J, Kohno T, Georgiev SK, Ikoma M, Ishii H, Petrenko AB, Baba H: Taurine activates glycine and gamma-aminobutyric acid $A$ receptors in rat substantia gelatinosa neurons. Neuroreport 2008, 19:333-337.

12. Welsh BT, Kirson D, Allen HM, Mihic SJ: Ethanol enhances taurineactivated glycine receptor function. Alcohol Clin Exp Res 2010, 34:1634-1639.

13. Kato S, Umeda M, Takeeda M, Kanatsu K, Takeuchi K: Effect of taurine on ulcerogenic response and impaired ulcer healing induced by monochloramine in rat stomachs. Aliment Pharmacol Ther 2002, 16(Suppl 2):35-43.

14. Son M, Kim HK, Kim WB, Yang J, Kim BK: Protective effect of taurine on indomethacin-induced gastric mucosal injury. Adv Exp Med Biol 1996, 403:147-155.

15. Murakami M, Yoo JK, Teramura S, Yamamoto K, Saita H, Kita T, Miyake T: Protective effect of taurine against ammonia-induced gastric mucosal lesions in rats. Jpn J Pharmacol 1989, 51:569-571.

16. Ma N, Sasaki T, Sakata-Haga H, Ohta K, Gao M, Kawanishi S, Fukui Y: Protective effect of taurine against nitrosative stress in the stomach of rat with water immersion restraint stress. Adv Exp Med Biol 2009, 643:273-283.

17. Ma N, Ding X, Miwa T, Semba R: Immunohistochemical localiztion of taurine in the rat stomach. Adv Exp Med Biol 2003, 526:229-236.

18. Lobo MV, Alonso F, Martin del Rio R: Immunocytochemical localization of taurine in different muscle cell types of the dog and rat. Histochem J 2000, 32:53-61.

19. Baetge G, Gershon MD: GABA in the PNS: demonstration in enteric neurons. Brain Res Bull 1986, 16:421-424.

20. Reis HJ, Vanden Berghe P, Romano-Silva MA, Smith TK: GABA-induced calcium signaling in cultured enteric neurons is reinforced by activation of cholinergic pathways. Neuroscience 2006, 139:485-494.

21. Goaillard JM, Marder E: Exciting guts with GABA. Nat Neurosci 2003, 6:1121-1122
22. Tsai LH, Taniyama K, Tanaka C: gamma-Aminobutyric acid stimulates acid secretion from the isolated guinea pig stomach. Am J Physiol 1987, 253: G601-G606.

23. Tsai LH: Function of GABAergic and glutamatergic neurons in the stomach. J Biomed Sci 2005, 12:255-266.

24. L'Amoreaux WJ, Marsillo A, El Idrissi A: Pharmacological characterization of $\mathrm{GABA}_{A}$ receptors in taurine-fed mice. J Biomed Sci 2010, 17(Suppl 1):S14

25. Jiang Z, Krnjevic K, Wang F, Ye JH: Taurine activates strychnine-sensitive glycine receptors in neurons freshly isolated from nucleus accumbens of young rats. J Neurophysiol 2004, 91:248-257.

26. Kontro P, Oja SS: Interactions of taurine with $G_{A B A}$ binding sites in mouse brain. Neuropharmacology 1990, 29:243-247.

27. Lin CT, Li HZ, Wu JY: Immunocytochemical localization of L-glutamate decarboxylase, gamma-aminobutyric acid transaminase, cysteine sulfinic acid decarboxylase, aspartate aminotransferase and somatostatin in rat retina. Brain Res 1983, 270:273-283.

28. Magnusson KR, Madl JE, Clements JR, Wu JY, Larson AA, Beitz AJ: Colocalization of taurine- and cysteine sulfinic acid decarboxylase-like immunoreactivity in the cerebellum of the rat with monoclonal antibodies against taurine. J Neurosci 1988, 8:4551-4564.

29. Staines WA, Benjamin AM, McGeer EG: Cysteinesulfinate decarboxylase activity as an index of taurine-containing structures. J Neurosci Res 1980 5:555-562.

30. Tsai LH, Tsai W, Wu JY: Effect of L-glutamic acid on acid secretion and immunohistochemical localization of glutamatergic neurons in the rat stomach. J Neurosci Res 1994, 38:188-195.

31. Ma N, Aoki E, Semba R: An immunohistochemical study of aspartate, glutamate, and taurine in rat kidney. J Histochem Cytochem 1994, 42:621-626

32. Bradford MM: A rapid and sensitive method for the quantitation of microgram quantities of protein utilizing the principle of protein-dye binding. Anal Biochem 1976, 72:248-254

33. Kodama M, Tsukada H, Ooya M, Onomura M, Saito T, Fukuda K, Nakamura H, Taniguchi T, Tominaga M, Hosokawa M, Fujita J, Seino Y: Gastric mucosal damage caused by monochloramine in the rat and protective effect of taurine: endoscopic observation through gastric fistula. Endoscopy 2000, 32:294-299.

34. Tsai $L H$, Lee $Y J, W u J Y$ : Role of $N$-methyl-D-aspartate receptors in gastric mucosal blood flow induced by histamine. J Neurosci Res 2004, 77:730-738.

35. Young $\mathrm{TL}$, Cepko $\mathrm{CL}$ : A role for ligand-gated ion channels in rod photoreceptor development. Neuron 2004, 41:867-879.

36. Kondziella D, Ludemann W, Brinker T, Sletvold O, Sonnewald U: Alterations in brain metabolism, CNS morphology and CSF dynamics in adult rats with kaolin-induced hydrocephalus. Brain Res 2002, 927:35-41.

37. Lopez-Colome AM: Taurine receptors in CNS membranes: binding studies. Adv Exp Med Biol 1981, 139:293-310.

38. Soll AH: The interaction of histamine with gastrin and carbamylcholine on oxygen uptake by isolated mammalian parietal cells. J Clin Invest 1978, 61:381-389.

39. Narahashi T: Chemicals as tools in the study of excitable membranes. Physiol Rev 1974, 54:813-889.

40. Hussy N, Deleuze C, Pantaloni A, Desarmenien MG, Moos F: Agonist action of taurine on glycine receptors in rat supraoptic magnocellular neurones: possible role in osmoregulation. J Physiol 1997, 502(Pt 3):609-621.

41. El Idrissi A, Trenkner E: Taurine as a modulator of excitatory and inhibitory neurotransmission. Neurochem Res 2004, 29:189-197.

42. El Idrissi A, Boukarrou L, Splavnyk K, Zavyalova E, Meehan EF, L'Amoreaux W: Functional implication of taurine in aging. Adv Exp Med Biol 2009, 643:199-206.

43. Louzada PR, Paula Lima AC, Mendonca-Silva DL, Noel F, De Mello FG, Ferreira ST: Taurine prevents the neurotoxicity of beta-amyloid and glutamate receptor agonists: activation of GABA receptors and possible implications for Alzheimer's disease and other neurological disorders. Faseb J 2004, 18:511-518.

44. Wu JY, Tang XW, Tsai WH: Taurine receptor: kinetic analysis and pharmacological studies. Adv Exp Med Biol 1992, 315:263-268.

45. Bulley S, Shen W: Reciprocal regulation between taurine and glutamate response via $\mathrm{Ca}^{2+}$-dependent pathways in retinal third-order neurons. $J$ Biomed Sci 2010, 17(Suppl 1):S5. 
46. Frosini M, Sesti C, Dragoni S, Valoti M, Palmi M, Dixon HB, Machetti F, Sgaragli G: Interactions of taurine and structurally related analogues with the GABAergic system and taurine binding sites of rabbit brain. $\mathrm{Br} J$ Pharmacol 2003, 138:1163-1171.

47. Kontro P, Oja SS: Co-operativity in sodium-independent taurine binding to brain membranes in the mouse. Neuroscience 1987, 23:567-570.

48. Remy C, Kirchhoff P, Hafner P, Busque SM, Mueller MK, Geibel JP, Wagner CA: Stimulatory pathways of the Calcium-sensing receptor on acid secretion in freshly isolated human gastric glands. Cell Physiol Biochem 2007, 19:33-42.

49. Geibel JP, Wagner CA, Caroppo R, Qureshi I, Gloeckner J, Manuelidis L, Kirchhoff $P$, Radebold K: The stomach divalent ion-sensing receptor scar is a modulator of gastric acid secretion. J Biol Chem 2001, 276:39549-552.

50. Dufner MM, Kirchhoff P, Remy C, Hafner P, Muller MK, Cheng SX, Tang LQ, Hebert SC, Geibel JP, Wagner CA: The calcium-sensing receptor acts as a modulator of gastric acid secretion in freshly isolated human gastric glands. Am J Physiol Gastrointest Liver Physiol 2005, 289:G1084-G1090.

51. Hinojosa J, Primo J: Effect of verapamil, a calcium antagonist, on the gastric secretion stimulated by histamine or sham-feeding. Rev Esp Enferm Dig 1990, 78:9-13.

doi:10.1186/1423-0127-18-11

Cite this article as: Huang et al:: Role of taurine on acid secretion in the rat stomach. Journal of Biomedical Science 2011 18:11.

\section{Submit your next manuscript to BioMed Central} and take full advantage of:

- Convenient online submission

- Thorough peer review

- No space constraints or color figure charges

- Immediate publication on acceptance

- Inclusion in PubMed, CAS, Scopus and Google Scholar

- Research which is freely available for redistribution

Submit your manuscript at www.biomedcentral.com/submit
Biomed Central 